\title{
Influence of feeding systems on selected beef quality and sensory attributes
}

\author{
E. Moholisa ${ }^{1 \#}$, P.E. Strydom ${ }^{1,2 \#}$, I. Van Heerden ${ }^{1}$ \& A. Hugo ${ }^{3}$ \\ ${ }^{1}$ Animal Production Institute, Agricultural Research Council, Private Bag X2, Irene, South Africa \\ ${ }^{2}$ Department of Animal Sciences, Stellenbosch University, Stellenbosch 7602, South Africa \\ ${ }^{3}$ Department of Microbial, Biochemical and Food Biotechnology, University of Free-State, Bloemfontein, South \\ Africa
}

(Received 10 March 2019; Accepted 31 July 2019; First published online 31 January 2020)

\begin{abstract}
Copyright resides with the authors in terms of the Creative Commons Attribution 4.0 South African Licence.
See: http://creativecommons.org/licenses/by/4.0/za

Condition of use: The user may copy, distribute, transmit and adapt the work, but must recognise the authors and the South African Journal of Animal Science.
\end{abstract}

\begin{abstract}
Feeding systems and other factors associated with processing influence meat quality, and therefore sensory attributes. This study was conducted to assess the meat quality attributes of young grain-fed and older grass-fed steers that mostly affect consumer acceptability of beef. Eighty Bonsmara steers consisting of 20 each of A-age (0-tooth) grain-fed (AC) and grain-fed supplemented with zilpaterol (AZ), 20 each of grass-fed $A B(1-2$ teeth) and B-age ( 3 - 6 teeth) animals were used. This combination represented the typical feeding systems of South Africa and other countries using similar classification systems, therefore describes the typical feeding systems of the South African beef industry. The longissimus lumborum (LL), semitendinosus (ST), and biceps femoris (BF) muscles were tested for colour, moisture properties, lipid oxidation and sensory attributes. It was found that diet in combination with animal age influenced meat colour. Muscles of the older grass-fed steers were generally darker and duller (darker red) compared to muscles of young grain-fed animals. Moisture loss was consistently higher in zilpaterol supplemented meat samples compared to the feedlot controls, while muscles of the grass-fed animals had lower moisture loss. A sensory panel clearly distinguished between cuts of grain-fed ( $A Z$ and $A C)$ and grass-fed carcasses (AB and $B$ ) on the grounds of flavour characteristic. The $A B$ and $B$ cuts scored higher for grassy, animal-like and rancid flavour overtones and lower for roasted flavour and sourness than $A Z$ and $A C$ grain-fed cuts. This indicated that typical flavours related to diet define expected eating quality.
\end{abstract}

Keywords: age, grain, grass, meat quality, zilpaterol

${ }^{\#}$ Corresponding authors: moholisae1@arc.agric.za, pstrydom@arc.agric.za

\section{Introduction}

Beef cattle in South Africa are either grain-fed or raised on pasture. Feedlot animals are normally younger animals and are often supplemented with the beta-agonist, zilpaterol. Zilpaterol is used in animal production to enhance growth performance and produce larger carcasses (Avendaño-Reyes et al., 2006; Strydom et al., 2009; Meraz-Murillo et al., 2017). Under the South African carcass classification system, most carcasses from grain-fed animals are classified in the A-age class (0 incisors) (Government notice No. R342, 1999). Most pasture-raised animals are older animals with $1-2$ and $3-6$ permanent incisors, and are classified as AB and B-age, respectively. The C-age (7 or more incisors) are cull cows or bulls, also grown on pasture. Beta-agonists are never used on pasture animals. The options for either of these production systems are influenced mostly by the availability and type of natural resources, local consumer demand and commercial viability (Frylinck et al., 2013). Production systems, and other production factors notably influence meat quality, therefore sensory attributes, ultimately consumer acceptability of meat. Consumer preferences are related to visual appearance (e.g. colour, packaging, fatness, purge) before consumption and perception of both texture, aroma and flavour during consumption, although these are not homogenous among consumers (Joo et al., 2013; Font-i-furnols \& Guerrero, 2014). Therefore, consumer perspectives on meat quality are complex (Henchion et al., 2017). 
Feeding systems effects on sensory attributes of beef have been extensively researched. Most of the American studies reported grain-fed beef to be preferred over grass-fed beef from both consumer and trained sensory panels (Van Elswyk \& McNeill, 2014). Brewer and Calkins (2003) and Muir et al. (1998) reported that grass-fed animals produce meat that is less tender, with poorer flavour and overall acceptability/desirability than grain-fed animals. However, some studies, particularly from Ireland, often do not or show little differences in meat quality between grain- and grass-fed animals (French et al., 2000; Noci et al., 2005; Moloney et al., 2011). In a blind test study consisting of Spanish, French, and British consumers, beef from grass-fed animals was rated higher than beef from cattle fed concentrates (Realini et al., 2013). According to Moloney et al. (2011), many of the reported comparisons of grass- and grain-fed beef are frequently influenced by confounding factors such as animal age, management practices pre- and postslaughter, and also cultural preferences of the sensory panel used.

It is reported that palatability traits decrease as carcass maturity increases (Shorthose \& Harris, 1990; Schönfeldt \& Strydom, 2011). Various reports showed that meat from older animals is less tender and less juicy than meat from younger animals (Shorthose \& Harris, 1990; Hilton et al., 1998; Sañudo et al., 1998). In contrast, other studies observed no age class effects for sensory attributes (flavour, taste, juiciness and offflavours, and overall acceptability) (Powell, 1991; Galli et al., 2008).

The use of beta-agonist/s (BA/s) in animal production could have a large effect on meat quality. Betaagonists improve growth efficiency and increase carcass yield by increasing muscle deposition to the cost of fat deposition (Avendaño-Reyes et al., 2006; Meraz-Murillo et al., 2017). However, their beneficial effects on muscle mass deposition also lead to changes in meat quality and palatability (Cônsolo et al., 2016). Regardless of different trial conditions, there is consensus about reduced tenderness of BA supplemented beef, more specifically when zilpaterol is used (Avendaño-Reyes et al., 2006; Strydom et al., 2011; Garmyn et al., 2014; Meraz-Murillo et al., 2017); however, reports on other meat quality and palatability traits are somewhat inconclusive. Avendaño-Reyes et al. (2006), Delmore et al. (2010), Cônsolo et al.(2016), and Meraz-Murillo et al. (2017) reported no negative effects on meat quality attributes such as lean colour, while other studies reported reduced red colour in zilpaterol supplemented beef (Hilton et al., 2009; Hope-Jones et al., 2012, Garmyn et al., 2014). Some studies reported reduced juiciness in beef of zilpaterol supplemented animals compared to the controls (Hilton et al., 2009; Cônsolo et al., 2016), while others found no differences (Arp et al., 2014; Garmyn et al., 2014). Regarding flavour, Tatum (2008) indicated that management practices that lead to reduction in intramuscular fat such as excessive use of aggressive growth enhancement technologies like the use of BAs is detrimental to the production of beef with good flavour. For instance, trained panels found that zilpaterol reduced flavour intensity of longissimus steaks aged 14 days, while no off-flavours were detected (Hilton et al., 2009; Leheska et al., 2009). Conversely, Cônsolo et al. (2016) found no effects of zilpaterol on beef flavour.

Although there have been many reports on differences in quality between grass- and grain-fed beef there is limited information describing the combined effects of feeding regime, age and the use of growth enhancers as portrayed in different production systems. In South Africa and other countries using similar carcass classification systems, these combinations describe the typical production systems of the beef industry. This implies that consumers rely on an integrated production system when making choices for the final product, and that, is determined by the classification system. The South African red meat classification system based mainly on animal age and fatness, has been criticised for satisfying the meat sellers without providing the consumer with any measure of expected eating quality (Sonji et al., 2017). In this study, we investigated the combined effects of feeding regime accompanied by differences in animal age as well as the utilisation of the zilpaterol in a typical feeding system of the South African beef industry. It could be expected that age, feeding regime and beta-agonists may affect meat quality paramaters of different muscle types differently. Therefore, we used three economically important muscles of beef carcass, i.e. Iongissimus lumborum, semitendinosus and biceps femoris.

\section{Materials and Methods}

The procedures involved in sourcing, transport, feeding and slaughtering of the animals used in this study were approved by the Animal Ethics Committee of the ARC (Certificate number: APIEC11/030). Briefly, the study consisted of two main groups of Bonsmara-type steers namely grain- and grass- fed animals. The grass-fed animals $(n=40)$ were sourced from farmers involved in the ox trade. Dentition was verified during selection of the animals so that two age groups $(n=20 /$ group) could be selected according to permanent incisors (p.i.), namely $A B$ (1-2 p.i. and B (3-6 p.i.) based on the beef carcass classification system of South Africa (Government notice No. R342, 1999).

Forty (40) weaners (9 to 11 months; $\sim 220 \mathrm{~kg}$ ) represented the grain-fed group and were selected from a commercial feedlot (A-age, 0 incisors). These animals were implanted with Ralgro ( $36 \mathrm{mg}$ zeranol; Schering-Plough, South Africa) and re-implanted with Revalor-S (140 mg trenbolone acetate and $28 \mathrm{mg}$ 
$\beta$-oestradiol; Intervet, South Africa) 49 days later. The animals received a high concentrate commercial diet $(12 \mathrm{MJ} / \mathrm{kg}, 135 \mathrm{~g} / \mathrm{kg}$ protein on dry matter basis) (Table 1). Twenty (20) grain-fed animals received no betaagonist (AC), while the remaining 20 (AZ) were supplemented with the beta-agonist, zilpaterol hydrochloride (Intervet/Schering-Plough Animal Health, South Africa), at $0.15 \mathrm{mg} / \mathrm{kg}$ live weight for the final 30 days on feed plus a four-day withdrawal period before slaughter. Animals of the grain-fed groups had no permanent incisors (0 p.i).

Table 1 Feed ingredients (\%) and nutritional composition ( $\mathrm{g} \mathrm{kg}^{-1} \mathrm{DM}$ unless stated otherwise) of the finishing diet of two grain-fed groups

\begin{tabular}{lcc}
\hline Feed ingredient & AC & AZ \\
\hline Composition of diet: & & \\
Hominy chop & 62.00 & 62.00 \\
Wheat bran & 15.00 & 15.00 \\
Molasses meal & 10.00 & 10.00 \\
Cotton OCM & 5.00 & 5.00 \\
Grass Hay & 4.50 & 4.50 \\
Feedlime & 1.60 & 1.60 \\
Urea & 1.30 & 1.30 \\
Salt & 0.50 & 0.50 \\
Premix & 0.10 & 0.10 \\
Zilpaterol HCL mg kg & -1 & 0.30 \\
Nutrient composition & 0.00 & \\
Dry matter & & 873.3 \\
Crude protein & 873.3 & 149.2 \\
Fat & 149.2 & 63.4 \\
NDF & 63.4 & 444.8 \\
Crude fibre & 444.8 & 95.8 \\
ME (MJ kg ${ }^{-1}$ DM) & 95.8 & 11.4 \\
Starch & 11.4 & 278.5 \\
Calcium & 278.4 & 7.3 \\
P & 7.3 & 5.2 \\
\end{tabular}

AC: Treatment without Zilpaterol Hydrochloride (ZH) in diet, animals had zero p.i. AZ: Treatment with ZH in diet. ZH only supplemented for the last 30 on feed, with four days withdrawal before slaughter; animals had zero p.i. OCM: oil cake meal ${ }^{1}$ Premix containing: $6 \times 10^{6} \mathrm{IU}$ vitamin A, $3 \mathrm{~g}$ vitamin B1, $3.5 \mathrm{~g}, 30 \mathrm{~g}$ iron, $12 \mathrm{~g} \mathrm{Cu}, 50 \mathrm{~g}$, Monensin included at $33 \mathrm{mg} \mathrm{kg}^{-1}$ feed. NDF: Neutral detergent fibre ME: Metabolisable energy estimated from gross energy (NRC, 1996).

Animals were slaughtered according to standard commercial practice that included electrical stimulation ( $30 \mathrm{~s}$ duration, $400 \mathrm{~V}$ peak, 5 ms pulses at 15 pulses per sec) directly after exsanguination. The carcasses were chilled at $2{ }^{\circ} \mathrm{C}$ (entry and final room temperature) before sampling the day after slaughter. The longissimus lumborum (LL; $1^{\text {st }}$ to $5^{\text {th }}$ lumbar vertebrae), semitendinosus (ST: whole cut) and biceps femoris (BF: whole cut), of both sides of the carcass side were sampled. Each muscle was subdivided into $60 \mathrm{~mm}$ steaks that was allocated to colour, water holding capacity (WHC), lipid stability, and approximately one (1) kg portion was allocated to sensory analysis. All tests were performed on samples that were aged for 3 or 14 days at $4{ }^{\circ} \mathrm{C}$. Samples from one carcass side were aged for 3 days and those from the other side were aged for 14 days. The sample location for the different quality tests were the same for each animal on the respective muscles. The samples used for sensory analyses were stored frozen after ageing at $-20{ }^{\circ} \mathrm{C}$ until tests were conducted. All other tests were conducted on unfrozen meat.

A steak of $60 \mathrm{~mm}$ thickness of each of the three muscle cuts from both ageing times ( 3 and 14 days) was removed from vacuum packaging and bisected. The steaks were placed on Stryrofoam trays with the freshly cut surfaces facing upwards and left in a dark chiller $\left(2{ }^{\circ} \mathrm{C}\right)$ to bloom for 60 min. Colour 
measurements were performed with a Minolta colour meter (Model CR200, Osaka, Japan; 8 mm diameter measuring aperature, diffuse D65 illumination and $0^{\circ}$ viewing angle with specular component included). The CIE colour convention (CIE, 1986) was followed where the three fundamental outputs are $L^{*}$, $a^{\star}$ and $b^{\star}$. The $\mathrm{L}^{*}$ is lightness on a scale of 0 (all light absorbed) to 100 (all light reflected); $\mathrm{a}^{*}$ spans from +60 (red) to -60

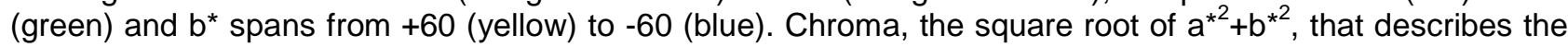
vividness was calculated using $a^{*}$ and $b^{*}$. Before recording muscle colour the measuring aperture was covered with a glass plate and the instrument was calibrated against a white plate $(\mathrm{C}$ : $\mathrm{Y}=94.4 \pm 0.05, \mathrm{x}=$ $0.313 \pm 0.07, y=0.320 \pm 0.07$ ). The average value of three measurements on the meat surface of a single steak was used. One of the two steaks used for colour was used to measure WHC.

Water-holding capacity (pressed out water) of both ageing times ( 3 and 14 days) was determined by calculating the ratio of meat area and liquid area after pressing a $400-600 \mathrm{mg}$ fresh meat sample of each cut on a filter paper (Whatman 4) sandwiched between two Perspex plates, and pressed at a constant pressure for one min according to the method described by Irie et al. (1996). The areas were measured by means of video image analyses (VIA) using a CC12 video camera (Olympus, Tokyo, Japan) and image processing and calculations by means of AnalySIS Life Science software package (Soft Imaging Systems Gmbh, Münster, Germany).

For sensory analysis, the LL and ST muscles were cut into $30 \mathrm{~mm}$ thick steaks the day before cooking and repackaged to determine thawing loss. The BF cut was thawed intact at the same conditions as the LL and ST muscles. All samples were thawed at $4{ }^{\circ} \mathrm{C}$ for 24 hours. Thawing loss was calculated as the difference between the sample mass before and after thawing and was expressed as a percentage of the starting mass. After thawing, the samples were cooked. The procedure for sensory analyses was previously described by Moholisa et al. (2017). Briefly, thawed LL and ST steaks were oven broiled at $170{ }^{\circ} \mathrm{C}$ to an internal temperature of $70{ }^{\circ} \mathrm{C}$. One $\mathrm{kg}$ portions of BF was prepared according to a moist heat cooking method and cooked in a pre-heated oven at $150^{\circ} \mathrm{C}$ to an internal temperature of $70{ }^{\circ} \mathrm{C}$. Raw and cooked weights, drip and evaporation loss and cooking times were recorded. Cooking loss was considered the combined loss of fat and stock drip and evaporation loss during cooking determined as weight differences between cooked and raw samples and expressed as percentage of raw sample weight.

$$
\text { Cooking loss } \%=\frac{\text { [sample raw mass after thawing-cooked sample mass] }}{\text { [sample raw mass after thawing] }} \times 100
$$

Sensory analyses of juiciness, aroma, typical beef and other flavour overtones were performed by a ten-member trained panel that was screened, selected and trained according to the American Meat Science Association guidelines (AMSA, 1995). Each muscle was tested individually. Samples from all four treatments ( $A C, A Z, A B$ and $B$ ) and two ageing periods ( 3 and 14 days) were randomly assigned to two taste sessions per day, with a 10 min interval between sessions, including four samples per session over 20 days per cut. The analysis was conducted over a 3-month period, including three days of training for each muscle before testing with breaks between individual cuts. Cubes of approximately $1 \mathrm{~cm}^{3}$ were cut from the centre of each steak (avoiding the dryer sides), wrapped in coded aluminium foil and presented to the panel to evaluate the sensory attributes described in Table 2. Sensory analysis of flavour was extended to six additional attributes related to the animal's diet that were identified in a pilot study. Panelists scored an eight (8) for extremely juicy, and extremely high intensities for aroma, overall flavour and all the additional flavour attributes, respectively. A score of one (1) was given for extremely dry, and extreme blandness for aroma, overall flavour and all the additional flavour attributes, respectively.

Lipid stability was evaluated on the remaining steak used for colour evaluation. Two (2)-Thiobarbituric acid (TBA; 4, 6-dihydroxy-2- mercapto-pyrimidin) as described by Raharjo et al. (1992) was used to measure lipid oxidation. Briefly, $5.0 \mathrm{~g}$ of meat was homogenised in $20 \mathrm{~mL} 5.0 \%$ (w/v) aqueous solution of trichloroacetic acid for one min using an Ultra Turrax homogenizer (T25, IKALabortechnik, Janke \& Kunkel, Staufen, Germany). The meat slurry was centrifuged at $9000 \mathrm{~g}$ for $5 \mathrm{~min}$ and the supernatant was filtered through a paper filter (MN615; Macherey-Nagel, Duren, Germany). The filtrate was made up to $25.0 \mathrm{~mL}, 4.0$ $\mathrm{mL}$ of filtrate was mixed with $4.0 \mathrm{~mL} 80 \mathrm{mM}$ TBA and incubated at $94 \pm 1{ }^{\circ} \mathrm{C}$ in a water bath for $5 \mathrm{~min}$. The absorbance of the pink pigment formed was scanned at $532 \mathrm{~nm}$ with a spectrophotometer (DU 7500 Beckman, Beckman Instruments Incorporated, Fullerton, California, USA). Results were expressed as 2thiobarbituric acid reactive substances (TBARS) as $\mathrm{mg}$ malonaldehyde per $\mathrm{kg}$ meat using a standard curve prepared from 1,1,3,3-tetraethoxypropane (malonaldehyde).

Sensory data for each muscle were analysed as a two-way factorial in a randomized block design with treatment $\times$ ageing period as main effects (factors) and tasting day as block factor. Sensory data were subjected to a test-retest analysis of variance (ANOVA) using the GLM (General Linear Models) procedure of SAS software version 9, (SAS, 1999) to test for panel reliability (ten judges). Judge $\times$ day and judge $\times$ 
treatment $\times$ ageing period interactions were used respectively as measures of temporal stability (precision) and internal consistency (homogeneity) of the panel. The Shapiro-Wilk test was performed on the standardised residuals from the model to test for normality (Shapiro, 1965). Furthermore, reliability of the panel was tested by Spearman's rank correlation using the CORR procedure in SAS. Correlations for all attributes were above 0.7 , which is regarded as 'reliable'. The data of thaw loss, cooking loss, WHC, colour and oxidative stability were subjected to ANOVA for a split-plot design (Snedecor \& Cochran, 1967) with the four treatments ( $A C, A Z, A B$, and $B$ ) as whole plots and the two ageing periods ( 3 and 14 days) as sub-plots. Means for the interactions between treatment $\times$ ageing or among treatments were separated using Fisher's protected $t$-least significant difference (LSD) (Snedecor \& Cochran, 1980). A probability level of 5\% was considered significant for all significance tests.

Table 2 Descriptions and definitions of attributes used by members of the trained sensory panel to describe meat samples

\begin{tabular}{ll}
\hline Descriptions & Definition \\
\hline $\begin{array}{l}\text { Aroma intensity } \\
\text { Sustained impression of juiciness }\end{array}$ & The intensity of the aroma of the sample when opening the foil \\
(SIJ) & The impression of juiciness that is formed while chewing \\
Overall flavour intensity & $\begin{array}{l}\text { This is a combination of typical beef related flavour, taste and mouth feel while } \\
\text { chewing and swallowing }\end{array}$ \\
Roasted flavour & Identification of caramelised browned fat flavour tones \\
Metallic/livery/bloody & $\begin{array}{l}\text { Identification of a metallic, livery or bloody taste typical of extended aged } \\
\text { products }\end{array}$ \\
Rancid & Identification of rancid, soapy or fatty off-flavour tones \\
Animal-like & Identification of musty, earthy, barnyard or sweaty flavour tones \\
Sour & Identification of a sour flavour often experienced in extended aged meat \\
Pasture-like or "Green" & Identification of grassy or shrubby flavour tones (plants)
\end{tabular}

\section{Results}

Table 3 shows $\mathrm{pH}$ and temperature values of muscles from the four feeding groups (measured at 24 hours post-mortem. The final 24 hour $\mathrm{pH}$ values of the LL grass-fed groups were significantly $(P<0.001)$ higher than that of grain-fed groups ( $A C$ and $A Z$ ) but well within the $\mathrm{pH}$ range for normal meat (Table 3 ) of between 5.4 - 5.7 under ideal conditions (Miller, 2007). Table 3 also showed that LL muscle of the AC group had higher $(P<0.001)$ final temperature than that of $A Z$ and both grass-fed groups. At 24 hours post-mortem the ST muscle of the AC group had a lower $(P<0.001) \mathrm{pH}$ value than that of the $A Z$ and grass-fed groups while the 24 hours $\mathrm{pH}$ values of the BF groups were not affected $(P=0.108)$ by treatment (Table 3$)$. The final muscle temperature of ST and BF for AC was also $(P<0.001)$ higher than muscles of $\mathrm{AZ}$ and $\mathrm{AB}$ grass-fed but did not differ from that of the $B$ grass-fed group. The AB muscles had $(P<0.001)$ lower final temperatures than that of B group (Table 3).

The influence of feeding systems on meat colour of LL, ST and BF cuts are presented in Table 4. Interactions were recorded between age groups and post-mortem ageing time for lightness (reflection) in all three muscles. Grass feeding combined with age generally reduced $L^{*}$ (lightness) values of all muscles significantly compared to that of grain-fed cattle ( $A C$ and $A Z$ ). Meat from older ( $A B$ and $B$ ) grass-fed cattle therefore produced darker meat than the younger grain-fed cattle ( $A C$ and $A Z$ ). Higher $L^{*}$ values were found for aged $A C L L$ cuts but not for $A Z, A B$ or $B$. In addition, post-mortem ageing reduced the $L^{*}$ values of the $S T$ cuts of the $A C$ treatment. The $L^{*}$ values respectively increased and decreased between 3 and 14 days for LL and ST muscles of this treatment group but not for $A Z, A B$ or $B$ treatments. The ST muscle was generally lighter or paler (recorded higher $L^{*}$ values) than the other two muscles.

The AZ group generally recorded higher chroma values than the two grass-fed groups for all three cuts and both ageing periods (Table 4$)$. This was due to higher values for redness $\left(a^{*}\right)$, yellowness $\left(b^{*}\right)$ or both. The chroma value for AC aged for 14 days was significantly higher than that of all other treatment combinations. 
Table 3 Temperature and pH values of the four feeding systems measured at 24 hours post- mortem

\begin{tabular}{llccccc}
\hline Treatment & & $\mathrm{AC}$ & $\mathrm{AZ}$ & $\mathrm{AB}$ & $\mathrm{B}$ & $P$-value \\
\hline \multirow{3}{*}{ Longissimus lumborum } & $\mathrm{pH}$ & $5.2^{\mathrm{a}} \pm 0.05$ & $5.2^{\mathrm{a}} \pm 0.09$ & $5.4^{\mathrm{b}} \pm 0.21$ & $5.4^{\mathrm{b}} \pm 0.29$ & $<0.001$ \\
& Temperature & $8.0^{\mathrm{c}} \pm 0.95$ & $5.6^{\mathrm{a}} \pm 1.08$ & $6.3^{\mathrm{ab}} \pm 1.43$ & $6.9^{\mathrm{b}} \pm 1.16$ & $<0.001$ \\
Semitendinosus & $\mathrm{pH}$ & $5.2^{\mathrm{a}} \pm 0.04$ & $5.5^{\mathrm{b}} \pm 0.07$ & $5.5^{\mathrm{b}} \pm 0.26$ & $5.5^{\mathrm{b}} \pm 0.22$ & $<0.001$ \\
& Temperature & $9.9^{\mathrm{b}} \pm 0.89$ & $7.6^{\mathrm{a}} \pm 0.95$ & $8.0^{\mathrm{a}} \pm 1.10$ & $9.0^{\mathrm{b}} \pm 1.64$ & $<0.001$ \\
Biceps femoris & $\mathrm{pH}$ & $5.3 \pm 0.08$ & $5.4 \pm 0.03$ & $5.4 \pm 0.18$ & $5.4 \pm 0.19$ & $=0.108$ \\
& Temperature & $11.3^{\mathrm{b}} \pm 0.83$ & $8.0^{\mathrm{a}} \pm 1.28$ & $9.1^{\mathrm{a}} \pm 1.84$ & $11.0^{\mathrm{b}} \pm 1.54$ & $<0.001$
\end{tabular}

\footnotetext{
${ }^{a, b}$ Row means differ significantly at $P<0.05$; AC: Treatment without Zilpaterol Hydrochloride (ZH) in the diet, animals had zero p.i, AZ: Treatment with $\mathrm{ZH}$ in diet-ZH only supplemented for the last 30 days on feed, with four days withdrawal before slaughter; animals had zero p.i., AB: Grass-fed steers with 1-2 p.i., B: Grass-fed steers with 3-6 p.i.
}

Mean values showing the effects of feeding system and post-mortem ageing on moisture properties are presented in Table 5. Small but significant variation was recorded for WHC (pressed out water) for LL and BF muscles, although no specific pattern with regards to the treatment effects (feeding regime/age and post-mortem ageing) were observed. Samples aged for 14 days tended to show higher purge than those aged for three days. For certain muscles combined with treatment groups this difference was significant, but no specific pattern was observed. At three days ageing, $A B$ and $B$ samples recorded lower purge than $A Z$ for the $L L$ muscle, while $A B$ recorded lower purge than $A C$ for the ST muscle. At 14 days ageing $A Z$ recorded the highest purge for all three muscles and differed significantly from $A B$ for the LL muscle, from $A B$ and $B$ for the ST muscle and from B and AC, for the BF muscle.

Post-mortem ageing had no effect on total cooking loss for any cut (Table 5). For the LL cut, $A Z$ treatment aged for three days recorded the highest cooking loss, while $A B$ aged for 14 days recorded the lowest value with a difference of 2.5\% units. The AZ BF cuts recorded higher cooking losses at 3 and 14 days $(P<0.001)$ than BF cuts of all AB and B treatments and AC aged for three days. The ST cuts showed no significant differences among treatments.

Cooked samples were scored for three attributes of tenderness (Moholisa et al., 2017), juiciness, aroma intensity and various flavour overtones (Table 6). Within each treatment group post-mortem ageing had no effect on scores of any sensory attribute except for the flavour overtone "Animal-Like", where ST muscle of the B treatment group scored higher at 14 days compared to three days ageing $(P<0.001)$. Sustained juiciness was similar for older grass-fed $A B$ and $B$ age groups and the younger AC grain-fed group for all three muscles. The zilpaterol treated group (AZ) scored consistently lower for juiciness compared to other treatments and the effect was most noticeable for the BF muscle.

No specific trend related to age or treatment was recorded for aroma intensity although differences ( $P$ $<0.001$ ) occurred among treatment $x$ ageing groups. For overall flavour intensity, the LL and ST muscles of the AC grain-fed group scored higher $(P<0.001)$ than B grass-fed group. The taste panel generally distinguished between grass- and grain-fed samples with regards to other flavour overtones, for all three muscles (Table 6). Higher intensities were scored for roasted flavour in AC LL cuts and for sourness in AZ LL cuts compared to grass-fed LL cuts, respectively (Table 6). Roasted flavour was generally scored higher for grain-fed samples than for grass-fed samples for all muscles, while sourness tended to be lower in grass-fed LL and BF cuts compared to grain-fed cuts, although the effect was not consistently significant. The panel also scored all cuts from grass-fed animals higher for animal-like, grassy and rancidity flavours and in most cases significant differences could be observed. Panelists were not able differentiate between $A C$ and $A Z$ in terms of the different flavour overtones in any of the three muscles.

The effect of treatment on lipid oxidation of LL, ST and BF muscles are presented in Table 7. The TBARS of LL $(P=0.003)$ and ST $(P=0.042)$ cuts showed significant interactions between age/feeding regime groups and post-mortem ageing, where TBARS values for longer aged samples tended to increase in the grain-fed groups but decreased in the grass-fed groups. Zilpaterol had no effect in this trend for the grain-fed groups. Ageing had no effect within treatment groups. Furthermore, within ageing treatment, only 14 dayaged AC cuts recorded higher TBARS than 14 days aged AB cuts in LL and ST. Standard deviations were fairly high pointing to large variation within treatment groups. 
Table 4 Influence of feeding systems on muscle colour of longissimus lumborum, semitendinosus and biceps femoris

\begin{tabular}{|c|c|c|c|c|c|c|c|c|c|}
\hline \multirow{2}{*}{$\begin{array}{l}\text { Treatment } \\
\text { DPM }\end{array}$} & \multicolumn{2}{|c|}{$A C$} & \multicolumn{2}{|c|}{$A Z$} & \multicolumn{2}{|c|}{$A B$} & \multicolumn{2}{|c|}{ B } & \multirow{2}{*}{$P$-value } \\
\hline & 3 & 14 & 3 & 14 & 3 & 14 & 3 & 14 & \\
\hline \multicolumn{10}{|c|}{ Longissimus lumborum } \\
\hline$L^{*}$ - value & $42.3^{b} \pm 2.72$ & $52.9^{c} \pm 2.75$ & $43.5^{b} \pm 2.78$ & $43.1^{b} \pm 2.61$ & $35.2^{a} \pm 2.66$ & $35.4^{\mathrm{a}} \pm 2.81$ & $34.2^{\mathrm{a}} \pm 1.96$ & $34.8^{\mathrm{a}} \pm 2.66$ & $<0.001$ \\
\hline$a^{*}$ - value & $15.8^{\mathrm{a}} \pm 1.07$ & $19.9^{b} \pm 1.90$ & $19.0^{b} \pm 1.87$ & $19.2^{b} \pm 1.67$ & $14.3^{\mathrm{a}} \pm 2.01$ & $15.2^{\mathrm{a}} \pm 2.26$ & $14.8^{\mathrm{a}} \pm 1.52$ & $15.3^{\mathrm{a}} \pm 2.13$ & $<0.001$ \\
\hline$b^{*}$ - value & $8.9^{b} \pm 1.10$ & $14.9^{\mathrm{d}} \pm 1.17$ & $11.1^{\mathrm{c}} \pm 1.26$ & $11.5^{c} \pm 0.86$ & $7.5^{\mathrm{ab}} \pm 2.07$ & $7.7^{\mathrm{ab}} \pm 1.78$ & $7.1^{\mathrm{a}} \pm 1.10$ & $7.8^{\mathrm{ab}} \pm 1.60$ & $<0.001$ \\
\hline Chroma & $18.1^{\mathrm{a}} \pm 1.42$ & $25.9^{C} \pm 2.00$ & $21.6^{b} \pm 2.15$ & $22.4^{b} \pm 1.79$ & $16.3^{\mathrm{a}} \pm 2.55$ & $17.1^{\mathrm{a}} \pm 2.70$ & $16.5^{\mathrm{a}} \pm 1.74$ & $17.3^{\mathrm{a}} \pm 2.46$ & $<0.001$ \\
\hline \multicolumn{10}{|c|}{ Semitendinosus } \\
\hline$L^{*}$ - value & $49.7^{\mathrm{b}} \pm 2.86$ & $43.4^{a} \pm 2.16$ & $51.7^{\mathrm{b}} \pm 2.49$ & $50.1^{\mathrm{b}} \pm 2.43$ & $43.1^{\mathrm{a}} \pm 3.40$ & $43.2^{\mathrm{a}} \pm 3.58$ & $42.8^{\mathrm{a}} \pm 4.86$ & $42.5^{\mathrm{a}} \pm 4.97$ & $<0.001$ \\
\hline$a^{\star}$ - value & $19.6 \pm 1.29$ & $18.7 \pm 1.43$ & $17.5 \pm 2.58$ & $18.1 \pm 2.26$ & $17.6 \pm 2.61$ & $17.9 \pm 2.61$ & $17.8 \pm 2.56$ & $18.1 \pm 2.90$ & $=0.193$ \\
\hline$b^{*}$ - value & $12.3^{\mathrm{ab}} \pm 1.21$ & $11.1^{\mathrm{a}} \pm 0.81$ & $14.0^{\mathrm{b}} \pm 1.33$ & $14.0^{\mathrm{b}} \pm 0.97$ & $10.8^{\mathrm{a}} \pm 1.86$ & $11.4^{\mathrm{a}} \pm 1.93$ & $11.2^{\mathrm{a}} \pm 2.26$ & $11.2^{\mathrm{a}} \pm 2.46$ & $<0.001$ \\
\hline Chroma & $23.3 \pm 1.45$ & $21.7 \pm 1.56$ & $22.2 \pm 2.66$ & $22.9 \pm 2.13$ & $20.7 \pm 3.10$ & $21.3 \pm 3.13$ & $21.1 \pm 3.10$ & $21.4 \pm 3.63$ & $=0.085$ \\
\hline \multicolumn{10}{|c|}{ Biceps femoris } \\
\hline$L^{*}$ - value & $45.2^{b} \pm 3.45$ & $43.6^{b} \pm 2.52$ & $46.1^{\mathrm{b}} \pm 2.19$ & $45.0^{b} \pm 2.56$ & $37.4^{a} \pm 1.85$ & $39.1^{\mathrm{a}} \pm 2.16$ & $37.7^{\mathrm{a}} \pm 2.29$ & $38.2^{\mathrm{a}} \pm 2.06$ & $<0.001$ \\
\hline$a^{*}$ - value & $19.7^{\mathrm{abc}} \pm 1.41$ & $19.7^{\mathrm{abc}} \pm 1.05$ & $21.5^{c} \pm 1.99$ & $21.1^{\mathrm{bc}} \pm 2.25$ & $19.2^{\mathrm{ab}} \pm 1.98$ & $20.1^{\mathrm{abc}} \pm 1.97$ & $19.0^{\mathrm{a}} \pm 2.31$ & $19.2^{\mathrm{ab}} \pm 2.39$ & $<0.001$ \\
\hline$b^{\star}$ - value & $11.2^{\mathrm{abc}} \pm 1.41$ & $11.4^{\mathrm{bcd}} \pm 0.75$ & $13.4^{\mathrm{d}} \pm 1.29$ & $13.0^{\text {cd }} \pm 0.99$ & $9.9^{\mathrm{ab}} \pm 1.43$ & $10.8^{\mathrm{ab}} \pm 1.52$ & $9.8^{\mathrm{a}} \pm 1.84$ & $10.3^{\mathrm{ab}} \pm 1.83$ & $<0.001$ \\
\hline Chroma & $22.8^{\mathrm{abc}} \pm 1.76$ & $22.8^{\mathrm{abc}} \pm 1.20$ & $25.4^{c} \pm 2.50$ & $24.7^{\mathrm{bc}} \pm 2.36$ & $21.6^{a} \pm 2.41$ & $22.6^{\mathrm{ab}} \pm 2.42$ & $21.4^{\mathrm{a}} \pm 2.83$ & $21.8^{\mathrm{a}} \pm 2.93$ & $<0.001$ \\
\hline
\end{tabular}

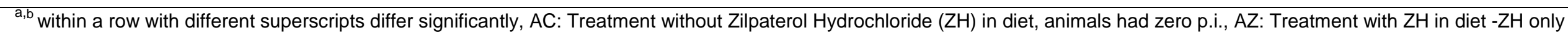

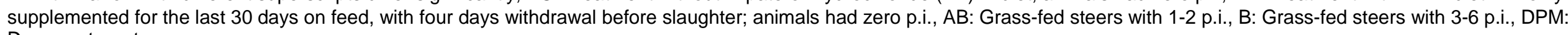
Days post-mortem. 
Table 5 Influence of feeding systems on moisture properties of longissimus lumborum, semitendinosus and biceps femoris

\begin{tabular}{|c|c|c|c|c|c|c|c|c|c|}
\hline \multirow{2}{*}{$\begin{array}{l}\text { Treatment } \\
\text { DPM }\end{array}$} & \multicolumn{2}{|c|}{$A C$} & \multicolumn{2}{|c|}{$A Z$} & \multicolumn{2}{|c|}{$A B$} & \multicolumn{2}{|c|}{ B } & \multirow{2}{*}{$P$-value } \\
\hline & 3 & 14 & 3 & 14 & 3 & 14 & 3 & 14 & \\
\hline \multicolumn{10}{|c|}{ Longissimus lumborum } \\
\hline WHC & $0.3^{\mathrm{a}} \pm 0.04$ & $0.4^{\mathrm{abc}} \pm 0.04$ & $0.4^{\mathrm{abc}} \pm 0.03$ & $0.4^{\mathrm{ab}} \pm 0.03$ & $0.4^{\mathrm{abc}} \pm 0.03$ & $0.4^{c} \pm 0.03$ & $0.4^{\mathrm{abc}} \pm 0.04$ & $0.4^{b c} \pm 0.03$ & $<0.001$ \\
\hline Purge loss & $3.5^{\mathrm{ab}} \pm 1.34$ & $5.5^{\mathrm{cd}} \pm 1.59$ & $4.7^{\mathrm{bcd}} \pm 1.20$ & $6.3^{d} \pm 1.00$ & $2.5^{\mathrm{a}} \pm 1.17$ & $4.4^{\mathrm{bc}} \pm 2.21$ & $2.6^{a} \pm 1.34$ & $4.7^{\mathrm{bcd}} \pm 2.47$ & $<0.001$ \\
\hline Thawing loss & $5.0^{b} \pm 0.69$ & $4.0^{\mathrm{ab}} \pm 0.80$ & $6.1^{c} \pm 1.07$ & $4.9^{b} \pm 0.93$ & $4.9^{b} \pm 0.89$ & $3.8^{\mathrm{a}} \pm 0.79$ & $4.7^{b} \pm 0.76$ & $3.8^{\mathrm{a}} \pm 1.13$ & $<0.001$ \\
\hline Cooked drip loss & $6.4^{\mathrm{d}} \pm 1.44$ & $6.0^{\mathrm{bcd}} \pm 1.33$ & $6.3^{d} \pm 1.09$ & $5.8^{c d} \pm 0.85$ & $4.2^{\mathrm{a}} \pm 1.42$ & $4.4^{\mathrm{ab}} \pm 1.01$ & $4.7^{\mathrm{abc}} \pm 1.37$ & $5.1^{\mathrm{abcd}} \pm 1.78$ & $<0.001$ \\
\hline Evaporation loss & $18.0 \pm 1.29$ & $18.3 \pm 1.96$ & $18.7 \pm 1.84$ & $18.2 \pm 1.67$ & $18.1 \pm 1.50$ & $17.1 \pm 1.97$ & $18.2 \pm 1.82$ & $17.5 \pm 2.02$ & $=0.164$ \\
\hline Total cooking loss & $24.0^{b c} \pm 1.85$ & $24.0^{b c} \pm 2.09$ & $25.0^{C} \pm 2.61$ & $24.1^{b c} \pm 1.84$ & $22.3^{\mathrm{ab}} \pm 1.52$ & $21.5^{\mathrm{a}} \pm 2.24$ & $22.8^{\mathrm{ab}} \pm 2.26$ & $23.0^{a b c} \pm 1.95$ & $<0.001$ \\
\hline \multicolumn{10}{|c|}{ Semitendinosus } \\
\hline WHC & $0.3 \pm 0.04$ & $0.3 \pm 0.03$ & $0.3 \pm 0.03$ & $0.3 \pm 0.02$ & $0.3 \pm 0.04$ & $0.3 \pm 0.04$ & $0.3 \pm 0.05$ & $0.3 \pm 0.04$ & $=0.067$ \\
\hline Purge loss & $3.2^{\mathrm{b}} \pm 1.33$ & $4.9^{c} \pm 1.32$ & $3.2^{\mathrm{ab}} \pm 0.86$ & $4.9^{c} \pm 1.65$ & $1.8^{\mathrm{a}} \pm 1.00$ & $3.2^{b} \pm 1.44$ & $2.1^{\mathrm{ab}} \pm 1.64$ & $3.0^{\mathrm{ab}} \pm 1.37$ & $<0.001$ \\
\hline Thawing loss & $6.3^{c} \pm 1.89$ & $5.1^{b c} \pm 1.60$ & $8.9^{d} \pm 1.09$ & $6.2^{c} \pm 1.16$ & $5.5^{c} \pm 1.25$ & $3.9^{\mathrm{ab}} \pm 0.65$ & $5.1^{b c} \pm 1.30$ & $3.8^{a} \pm 0.77$ & $<0.001$ \\
\hline Cooked drip loss & $4.8^{a} \pm 0.74$ & $5.0^{\mathrm{ab}} \pm 0.81$ & $4.6^{a} \pm 0.79$ & $4.8^{a} \pm 0.72$ & $4.6^{a} \pm 0.83$ & $4.6^{a} \pm 0.94$ & $5.8^{\mathrm{b}} \pm 1.17$ & $5.0^{\mathrm{ab}} \pm 0.90$ & $<0.001$ \\
\hline Evaporation loss & $22.4 \pm 1.56$ & $22.4 \pm 1.33$ & $23.1 \pm 2.21$ & $22.9 \pm 1.24$ & $22.3 \pm 2.23$ & $21.7 \pm 1.77$ & $21.3 \pm 2.56$ & $21.4 \pm 1.90$ & $=0.060$ \\
\hline Total cooking loss & $27.2 \pm 1.44$ & $27.3 \pm 1.23$ & $27.7 \pm 2.05$ & $27.8 \pm 1.52$ & $26.9 \pm 2.42$ & $26.3 \pm 2.03$ & $26.9 \pm 2.98$ & $26.4 \pm 2.31$ & $=0.370$ \\
\hline \multicolumn{10}{|c|}{ Biceps femoris } \\
\hline WHC & $0.3^{b} \pm 0.03$ & $0.3^{b} \pm 0.05$ & $0.3^{\mathrm{ab}} \pm 0.03$ & $0.3^{a} \pm 0.02$ & $0.3^{b} \pm 0.02$ & $0.3^{\mathrm{ab}} \pm 0.03$ & $0.3^{\mathrm{ab}} \pm 0.04$ & $0.3^{\mathrm{ab}} \pm 0.03$ & $<0.001$ \\
\hline Purge loss & $2.2^{\mathrm{a}} \pm 1.18$ & $3.8^{\mathrm{ab}} \pm 1.38$ & $3.2^{\mathrm{ab}} \pm 1.05$ & $5.7^{\mathrm{C}} \pm 1.23$ & $3.0^{\mathrm{ab}} \pm 1.55$ & $4.2^{b c} \pm 2.05$ & $2.5^{\mathrm{a}} \pm 1.07$ & $4.1^{b} \pm 1.48$ & $<0.001$ \\
\hline Thawing loss & $11.3^{\mathrm{b}} \pm 1.00$ & $10.4^{b} \pm 1.29$ & $11.4^{b} \pm 0.95$ & $10.0^{\mathrm{b}} \pm 2.87$ & $8.1^{\mathrm{a}} \pm 1.67$ & $8.0^{\mathrm{a}} \pm 1.73$ & $8.0^{a} \pm 1.72$ & $8.0^{\mathrm{a}} \pm 1.50$ & $<0.001$ \\
\hline Cooked drip loss & $22.7^{\mathrm{ab}} \pm 1.61$ & $24.1^{b c} \pm 1.65$ & $25.9^{\text {cd }} \pm 1.45$ & $27.2^{\mathrm{d}} \pm 1.34$ & $22.5^{\mathrm{ab}} \pm 1.67$ & $23.0^{\mathrm{ab}} \pm 2.52$ & $21.1^{\mathrm{a}} \pm 2.97$ & $23.0^{\mathrm{ab}} \pm 2.16$ & $<0.001$ \\
\hline Evaporation loss & $3.3 \pm 0.45$ & $3.4 \pm 0.43$ & $3.4 \pm 0.45$ & $3.5 \pm 0.61$ & $3.4 \pm 0.39$ & $3.4 \pm 0.68$ & $4.0 \pm 0.59$ & $3.3 \pm 0.56$ & $=0.770$ \\
\hline Total cooking loss & $26.0^{\mathrm{ab}} \pm 1.59$ & $27.5^{b c} \pm 1.71$ & $29.3^{c d} \pm 1.67$ & $30.0^{d} \pm 2.79$ & $26.0^{\mathrm{ab}} \pm 1.68$ & $26.0^{\mathrm{ab}} \pm 2.32$ & $25.0^{\mathrm{a}} \pm 2.76$ & $26.0^{\mathrm{ab}} \pm 1.81$ & $<0.001$ \\
\hline
\end{tabular}

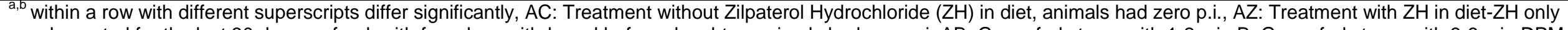

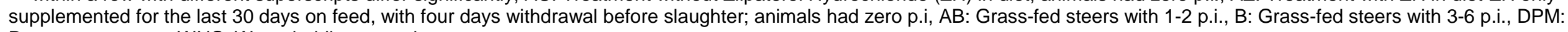
Days post-mortem, WHC: Water holding-capacity.
} 
Table 6 Influence of feeding systems on sensory properties of longissimus lumborum, semitendinosus and biceps femoris

\begin{tabular}{|c|c|c|c|c|c|c|c|c|c|}
\hline \multirow{2}{*}{$\begin{array}{l}\text { Treatment } \\
\text { DPM }\end{array}$} & \multicolumn{2}{|c|}{$A C$} & \multicolumn{2}{|c|}{$A Z$} & \multicolumn{2}{|c|}{$A B$} & \multicolumn{2}{|c|}{ B } & \multirow{2}{*}{$P$-value } \\
\hline & 3 & 14 & 3 & 14 & 3 & 14 & 3 & 14 & \\
\hline \multicolumn{10}{|c|}{ Longissimus lumborum } \\
\hline SIJ & $5.1^{b} \pm 0.30$ & $5.0^{a b} \pm 0.31$ & $4.8^{\mathrm{a}} \pm 0.33$ & $4.8^{a} \pm 0.29$ & $5.2^{b} \pm 0.23$ & $5.1^{\mathrm{ab}} \pm 0.27$ & $5.1^{b} \pm 0.31$ & $5.2^{b} \pm 0.25$ & $<0.001$ \\
\hline Aroma intensity & $5.6^{b c} \pm 0.30$ & $5.6^{a b c} c \pm 0.26$ & $5.6^{a b c} \pm 0.24$ & $5.4^{\mathrm{ab}} \pm 0.29$ & $5.6^{\mathrm{abc}} \pm 0.22$ & $5.7^{c} \pm 0.29$ & $5.4^{\mathrm{a}} \pm 0.24$ & $5.4^{a b} \pm 0.27$ & $<0.001$ \\
\hline Roasted flavour & $3.0^{\mathrm{cd}} \pm 0.75$ & $3.3^{d} \pm 0.73$ & $2.6^{\mathrm{abc}} \pm 0.53$ & $2.9^{b c d} \pm 0.59$ & $2.0^{\mathrm{a}} \pm 0.46$ & $2.3^{\mathrm{ab}} \pm 0.71$ & $2.0^{a} \pm 0.38$ & $2.4^{\mathrm{abc}} \pm 0.57$ & $<0.001$ \\
\hline Metallic/livery/bloody & $3.3^{\mathrm{ab}} \pm 0.54$ & $3.1^{\mathrm{a}} \pm 0.41$ & $3.6^{b} \pm 0.28$ & $3.2^{\mathrm{ab}} \pm 0.42$ & $3.5^{\mathrm{b}} \pm 0.48$ & $3.6^{b} \pm 0.51$ & $3.5^{\mathrm{ab}} \pm 0.45$ & $3.5^{\mathrm{ab}} \pm 0.41$ & $=0.002$ \\
\hline Rancid & $1.4^{\mathrm{ab}} \pm 0.32$ & $1.4^{\mathrm{ab}} \pm 0.26$ & $1.2^{\mathrm{a}} \pm 0.19$ & $1.2^{a} \pm 0.31$ & $2.0^{c} \pm 0.54$ & $1.8^{\mathrm{bc}} \pm 0.48$ & $2.1^{\mathrm{c}} \pm 0.54$ & $2.1^{c} \pm 0.54$ & $<0.001$ \\
\hline Animal-like & $1.6^{a} \pm 0.33$ & $1.6^{\mathrm{a}} \pm 0.35$ & $1.6^{\mathrm{a}} \pm 0.42$ & $1.5^{\mathrm{a}} \pm 0.44$ & $2.5^{b} \pm 0.53$ & $2.6^{b} \pm 0.66$ & $2.6^{b} \pm 0.61$ & $2.5^{b} \pm 0.72$ & $<0.001$ \\
\hline Sour & $3.3^{\mathrm{abc}} \pm 0.53$ & $3.5^{b c} \pm 0.54$ & $3.6^{c} \pm 0.49$ & $3.8^{\mathrm{C}} \pm 0.41$ & $3.0^{\mathrm{a}} \pm 0.64$ & $3.0^{\mathrm{ab}} \pm 0.45$ & $3.0^{\mathrm{ab}} \pm 0.61$ & $3.0^{\mathrm{ab}} \pm 0.48$ & $<0.001$ \\
\hline Pasture-like or "Green" & $1.4^{a} \pm 0.22$ & $1.7^{\mathrm{ab}} \pm 0.35$ & $1.4^{\mathrm{a}} \pm 0.22$ & $1.5^{\mathrm{a}} \pm 0.20$ & $2.0^{b c} \pm 0.35$ & $1.9^{b c} \pm 0.47$ & $2.1^{\mathrm{C}} \pm 0.45$ & $2.1^{b c} \pm 0.49$ & $<0.001$ \\
\hline Overall flavour intensity & $5.5^{\mathrm{bc}} \pm 0.34$ & $5.6^{c} \pm 0.29$ & $5.3^{\mathrm{abc}} \pm 0.27$ & $5.3^{\mathrm{abc}} \pm 0.24$ & $5.2^{\mathrm{ab}} \pm 0.33$ & $5.3^{\mathrm{abc}} \pm 0.36$ & $5.0^{a} \pm 0.24$ & $5.1^{a} \pm 0.33$ & $<0.001$ \\
\hline \multicolumn{10}{|c|}{ Semitendinosus } \\
\hline SIJ & $4.6^{\mathrm{bc}} \pm 0.32$ & $4.6^{b c} \pm 0.34$ & $4.3^{\mathrm{ab}} \pm 0.33$ & $4.2^{\mathrm{a}} \pm 0.35$ & $4.9^{\mathrm{cd}} \pm 0.30$ & $5.0^{\mathrm{cd}} \pm 0.24$ & $5.0^{c d} \pm 0.30$ & $5.1^{d} \pm 0.21$ & $<0.001$ \\
\hline Aroma intensity & $5.2^{\mathrm{abc}} \pm 0.32$ & $5.2^{\mathrm{abc}} \pm 0.32$ & $5.0^{\mathrm{ab}} \pm 0.42$ & $5.0^{a} \pm 0.31$ & $5.4^{\mathrm{bc}} \pm 0.45$ & $5.1^{a b c} \pm 0.46$ & $5.1^{b c} \pm 0.36$ & $5.5^{c} \pm 0.32$ & $<0.001$ \\
\hline Roasted flavour & $3.2^{b} \pm 0.55$ & $3.1^{b} \pm 0.62$ & $3.1^{\mathrm{b}} \pm 0.66$ & $3.2^{\mathrm{b}} \pm 0.50$ & $2.0^{\mathrm{a}} \pm 0.44$ & $2.1^{a} \pm 0.51$ & $2.0^{\mathrm{a}} \pm 0.52$ & $2.0^{\mathrm{a}} \pm 0.34$ & $<0.001$ \\
\hline Metallic/livery/bloody & $3.6 \pm 0.46$ & $3.1 \pm 0.46$ & $3.7 \pm 0.36$ & $3.4 \pm 0.59$ & $4.0 \pm 0.36$ & $4.0 \pm 0.40$ & $4.0 \pm 0.36$ & $4.0 \pm 0.46$ & $=0.153$ \\
\hline Rancid & $1.8^{\mathrm{a}} \pm 0.50$ & $1.6^{\mathrm{a}} \pm 0.45$ & $1.8^{\mathrm{a}} \pm 0.46$ & $1.4^{\mathrm{a}} \pm 0.33$ & $2.5^{\mathrm{b}} \pm 0.57$ & $2.4^{\mathrm{b}} \pm 0.43$ & $3.8^{\mathrm{b}} \pm 0.55$ & $3.7^{b} \pm 0.48$ & $<0.001$ \\
\hline Animal-like & $1.8^{\mathrm{a}} \pm 0.38$ & $2.0^{\mathrm{a}} \pm 0.58$ & $1.7^{\mathrm{a}} \pm 0.31$ & $1.5^{a} \pm 0.32$ & $3.0^{b} \pm 0.68$ & $3.1^{b c} \pm 0.65$ & $3.0^{b} \pm 0.48$ & $3.5^{c} \pm 0.49$ & $<0.001$ \\
\hline Sour & $3.2^{b c} \pm 0.43$ & $3.4^{\mathrm{d}} \pm 0.69$ & $3.2^{\mathrm{cd}} \pm 0.41$ & $3.2^{\mathrm{cd}} \pm 0.57$ & $3.0^{\mathrm{abc}} \pm 0.47$ & $3.6^{\mathrm{ab}} \pm 0.53$ & $3.0^{\mathrm{bcd}} \pm 0.41$ & $2.4^{\mathrm{a}} \pm 0.37$ & $<0.001$ \\
\hline Pasture-like or "Green" & $1.4^{\mathrm{a}} \pm 0.33$ & $1.5^{\mathrm{a}} \pm 0.36$ & $1.2^{\mathrm{a}} \pm 0.27$ & $1.4^{a} \pm 0.25$ & $2.2^{b} \pm 0.35$ & $2.5^{b} \pm 0.48$ & $2.5^{\mathrm{b}} \pm 0.60$ & $2.3^{\mathrm{b}} \pm 0.38$ & $<0.001$ \\
\hline Overall flavour intensity & $5.0^{b} \pm 0.22$ & $4.9^{\mathrm{ab}} \pm 0.14$ & $4.9^{\mathrm{ab}} \pm 0.20$ & $4.9^{\mathrm{ab}} \pm 0.25$ & $4.7^{\mathrm{a}} \pm 0.19$ & $4.7^{\mathrm{a}} \pm 0.24$ & $4.7^{\mathrm{a}} \pm 0.23$ & $4.7^{\mathrm{a}} \pm 0.16$ & $<0.001$ \\
\hline \multicolumn{10}{|c|}{ Biceps femoris } \\
\hline SIJ & $4.1^{b} \pm 0.32$ & $4.29^{b} \pm 0.38$ & $3.8^{\mathrm{a}} \pm 0.35$ & $3.7^{\mathrm{a}} \pm 0.37$ & $4.4^{b} \pm 0.33$ & $4.3^{b} \pm 0.32$ & $4.5^{b} \pm 0.39$ & $4.5^{b} \pm 0.45$ & $<0.001$ \\
\hline Aroma intensity & $5.4^{\mathrm{ab}} \pm 0.35$ & $5.5^{\mathrm{abc}} \pm 0.35$ & $5.2^{\mathrm{a}} \pm 0.46$ & $5.5^{\mathrm{abc}} \pm 0.41$ & $5.6^{b c} \pm 0.28$ & $5.8^{c} \pm 0.32$ & $5.6^{a b c} \pm 0.39$ & $5.7^{\mathrm{bc}} \pm 0.28$ & $<0.001$ \\
\hline Roasted flavour & $3.1^{c} \pm 0.61$ & $2.8^{\mathrm{bc}} \pm 0.64$ & $3.2^{\mathrm{c}} \pm 0.60$ & $3.5^{c} \pm 0.36$ & $2.3^{\mathrm{ab}} \pm 0.65$ & $2.1^{\mathrm{a}} \pm 0.64$ & $2.2^{\mathrm{a}} \pm 0.60$ & $2.1^{\mathrm{a}} \pm 0.46$ & $<0.001$ \\
\hline Metallic/livery/bloody & $3.6^{\mathrm{ab}} \pm 0.46$ & $4.0^{\mathrm{ab}} \pm 0.58$ & $3.8^{\mathrm{ab}} \pm 0.51$ & $3.6^{a} \pm 0.58$ & $4.0^{\mathrm{ab}} \pm 0.54$ & $4.3^{b} \pm 0.61$ & $4.1^{\mathrm{ab}} \pm 0.55$ & $4.0^{\mathrm{ab}} \pm 0.60$ & $=0.012$ \\
\hline Rancid & $1.5^{\mathrm{ab}} \pm 0.40$ & $1.5^{\mathrm{ab}} \pm 0.27$ & $1.2^{\mathrm{a}} \pm 0.23$ & $1.5^{\mathrm{ab}} \pm 0.46$ & $2.1^{b c} \pm 0.72$ & $2.1^{\mathrm{bc}} \pm 0.89$ & $2.2^{c} \pm 0.67$ & $2.1^{c} \pm 0.75$ & $<0.001$ \\
\hline Animal-like & $1.9^{a} \pm 0.46$ & $2.3^{\mathrm{a}} \pm 0.54$ & $1.9^{a} \pm 0.42$ & $1.8^{\mathrm{a}} \pm 0.40$ & $3.6^{\mathrm{b}} \pm 0.87$ & $3.7^{b} \pm 0.97$ & $3.6^{b} \pm 0.98$ & $3.8^{\mathrm{b}} \pm 0.76$ & $<0.001$ \\
\hline Sour & $4.1^{\mathrm{e}} \pm 0.52$ & $4.0^{\mathrm{de}} \pm 0.56$ & $3.8^{\mathrm{cde}} \pm 0.42$ & $3.6^{\text {bcde }} \pm 0.44$ & $3.2^{\mathrm{ab}} \pm 0.67$ & $3.5^{\mathrm{abcd}} \pm 0.60$ & $3.3^{a b c} \pm 0.48$ & $3.1^{a} \pm 0.34$ & $<0.001$ \\
\hline Pasture-like or "Green" & $1.8^{\mathrm{a}} \pm 0.41$ & $1.6^{\mathrm{a}} \pm 0.53$ & $1.8^{\mathrm{a}} \pm 0.52$ & $1.6^{a} \pm 0.37$ & $2.4^{\mathrm{b}} \pm 0.47$ & $2.6^{b} \pm 0.79$ & $2.5^{b} \pm 0.76$ & $2.4^{\mathrm{b}} \pm 0.52$ & $<0.001$ \\
\hline Overall flavour intensity & $5.3 \pm 0.19$ & $5.2 \pm 0.23$ & $5.2 \pm 0.23$ & $5.2 \pm 0.21$ & $5.1 \pm 0.22$ & $5.1 \pm 0.30$ & $5.1 \pm 0.22$ & $5.1 \pm 0.22$ & $=0.203$ \\
\hline
\end{tabular}

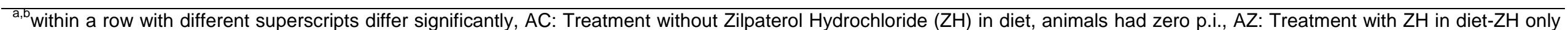

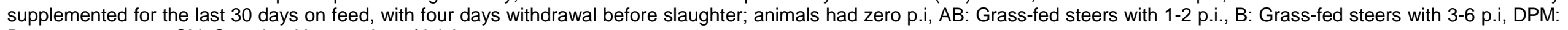
Days post-mortem, SIJ: Sustained impression of juiciness. 
Table 7 Effect of feeding system on lipid oxidation (TBARS, mg/malonaldehyde/kg meat) of longissimus lumborum, semitendinosus and biceps femoris

\begin{tabular}{|c|c|c|c|c|c|c|c|c|c|}
\hline \multirow{2}{*}{$\begin{array}{l}\text { Treatment } \\
\text { DPM }\end{array}$} & \multicolumn{2}{|c|}{$A C$} & \multicolumn{2}{|c|}{$A Z$} & \multicolumn{2}{|c|}{$A B$} & \multicolumn{2}{|c|}{$B$} & \multirow{2}{*}{$P$-value } \\
\hline & 3 & 14 & 3 & 14 & 3 & 14 & 3 & 14 & \\
\hline Longissimus lumborum & $0.07^{\mathrm{ab}} \pm 0.03$ & $0.09^{b} \pm 0.01$ & $0.06^{\mathrm{ab}} \pm 0.03$ & $0.07^{\mathrm{ab}} \pm 0.03$ & $0.08^{\mathrm{ab}} \pm 0.03$ & $0.05^{a} \pm 0.03$ & $0.08^{b} \pm 0.03$ & $0.06^{\mathrm{ab}} \pm 0.03$ & $=0.003$ \\
\hline Semitendinosus & $0.08^{\mathrm{ab}} \pm 0.02$ & $0.09^{b} \pm 0.03$ & $0.06^{a} \pm 0.04$ & $0.08^{a b} \pm 0.03$ & $0.08^{a b} \pm 0.02$ & $0.06^{a} \pm 0.03$ & $0.09^{b} \pm 0.04$ & $0.07^{\mathrm{ab}} \pm 0.04$ & $=0.042$ \\
\hline Biceps femoris & $0.08 \pm 0.03$ & $0.11 \pm 0.04$ & $0.07 \pm 0.03$ & $0.08 \pm 0.02$ & $0.08 \pm 0.03$ & $0.09 \pm 0.02$ & $0.09 \pm 0.04$ & $0.09 \pm 0.04$ & $=0.080$ \\
\hline
\end{tabular}

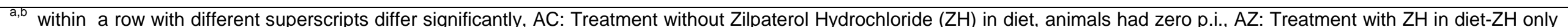

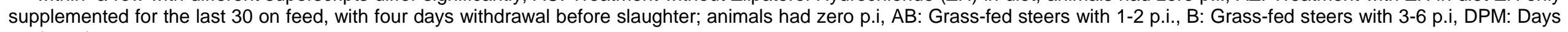
post-mortem. 


\section{Discussion}

The results of this study support previous research findings indicating that the various components of feeding systems influence meat quality which could lead to negative consumer acceptability of beef. Animal diet in combination with age influenced meat colour. In agreement with the work of Vestergaard et al. (2000), Bruce et al. (2004) and Sawyer et al. (2004), older grass-fed cattle (AB and B) produced darker meat (lower $L^{*}$ value) than the younger grain-fed cattle ( $A C$ and $A Z$ ). According to these studies, differences could be attributed to the age, diet and physical activity of animals. Older extensively reared animals have higher levels of the colour pigment, myoglobin, and according to Vestergaard et al. (2000) this may promote oxidative metabolism and lower muscle glycogen levels leading to higher final $\mathrm{pH}$ and darker colour. Furthermore, Bruce et al. (2004) reasoned that grain-finished carcasses are normally fatter and therefore muscle temperature decline is slower than in pasture animals. This could have been the same case with current study (Table 3). Combined with higher glycogen stores, $\mathrm{pH}$ decline is faster causing a scenario of low $\mathrm{pH}$ and high temperature during rigor mortis which is conducive to higher protein denaturation (Bruce \& Ball, 1990; Bruce et al., 2004), especially when electrical stimulation is applied. These conditions lead to more free water on the muscle surface and more light reflection (higher $L^{*}$ ) and more redness in muscle colour. The higher values for $L^{*}$ in the grain-fed groups coincided with higher purge in these groups. Redness or chroma were however not consistently higher in grain-fed groups (AC and AZ). Boakye and Mittal (1996) recorded higher values for lightness in vacuum aged samples and attributed the differences to increased retention of oxygen in the outer layers of freshly cut meat since the oxygen-utilizing enzymes in the deeper tissues became progressively inactivated by extended ageing. This effect was only noticed in aged LL in the AC treatment group. Ageing (14 days), that was more pronounced in the AC treatment (Moholisa et al., 2017), could have caused a more open structure in LL cuts due to structural protein breakdown causing more surface water and more light reflection (Ripoll et al., 2013). In older animals (AB and B), effects of higher final $\mathrm{pH}$ values (Table 3 ) on light reflection may have overshadowed the effects of ageing. Paler meat, i.e. higher L* values, was expected for AZ cuts compared to AC. Geesink et al. (1993) reported higher drip loss in BA treated LM muscle, which agree with our results. Higher water mobility was therefore expected to increase surface moisture resulting in higher reflectance by the aqueous layer. Furthermore, the shift towards whiter glycolytic fibre types and hypertrophy of these fibres caused by BA treatment (Gonzalez et al., 2009; Strydom et al., 2009; Vestergaard et al., 1994) would have reduced the heme iron pigment concentration and hence result in paler meat (Geesink et al., 1993). A combination of other factors could have overshadowed the effect of higher white muscle fibre content in AZ muscles. The extent of ageing in AZ LL cuts were less than that of AC LL cuts which could have influenced surface structure in this group in comparison with LL of the AC group (Ripoll et al., 2013).

Existing evidence for the effect of zilpaterol and other BA on the typical colour of meat (bright redness) is contradictory probably due to specific trial conditions in different studies. For zilpaterol in particular, Avendaño-Reyes et al. (2006) and Hope-Jones et al. (2012) recorded lower values for redness ( $a^{\star}$ ) and chroma. Rogers et al. (2010) recorded more desirable visual colour scores and instrumental colour values for loin steaks from zilpaterol treated steers in a colour shelf life study, while VanOverbeke et al. (2009) found no effect of zilpaterol on visual colour and discolouration of displayed top sirloin steaks, which agrees with our results on LL and ST cuts. Moloney et al. (1994) found an increase in glycolytic and glycolytic-oxidative fast-contracting muscle fibre types in animals supplemented with BAs, which could result in a better colour (redness) and a longer colour shelf life with these supplements for the following reasons; in control animals (non BA animals) a higher concentration of oxidative slow-contracting fibres (red) coincide with a higher concentration of mitochondria. When exposed to oxygen, mitochondria might compete with myoglobin for oxygen, thereby reducing the depth of the bright-red oxymyoglobin layer, and therefore the colour shelf life (Monin \& Ouali, 1992). However, in our study we measured ad hoc colour and did not test colour shelf life stability. Young et al. (1999) reported higher chroma values for meat with lower $\mathrm{pH}$ and also higher chroma values when muscle entered rigor at higher temperatures $\left(24^{\circ} \mathrm{C}\right.$ vs $\left.9^{\circ} \mathrm{C}\right)$ as were experienced with grain-fed cattle in our study, but in particular the AZ group. However, no consistent differences in chroma was recorded between $A C$ and $A Z$ in our study.

Moisture retention properties of meat are also important factor for consumer acceptability. High moisture loss in meat is considered as undesirable attribute of meat quality and have negative influence on consumer's decision to purchase meat. When considering the purge observed in this study (Table 5), the grain-fed cuts were more prone to moisture loss than grass-fed cuts, Furthermore, BA treatment seemed to affect moisture loss negatively when considering the purge loss of AZ compared to AC, at least in LL and ST cuts. Cooking losses were calculated as the total weight loss during cooking due to fat/stock drip loss and evaporation loss (Table 5). The ST and LL muscles were prepared according to a dry-heat cooking method (broiling), while BF was prepared according to a moist heat cooking method. Most of the total cooking losses in LL and ST (dry-heat cooking) were due to evaporative losses, while that of BF cuts were drip loss. Drip 
loss was made up of fat drip and meat stock, but relative proportions were not determined. According to Geesink et al. (1993) the higher cooking loss of the AZ BF cuts might be caused by larger muscle cells, a weaker support by cellular membranes and connective tissue and slightly increased water to protein ratio. The protein content of the AZ BF cuts was significantly higher than the other groups (Moholisa et al., 2018) that would have increased the protein to moisture ratio of this group. These effects were not noted in the other muscles.

Sensory aspects of meat are important for evaluating its suitability for consumer acceptance. The sensory scores in this study were mostly influenced by both diet and animal age and, in most cases, it was clear that panelists were able to differentiate between muscles of different feeding systems. However, zilpaterol showed no or little effect on most of the sensory scores compared to AC grain-fed and the grassfed beef, except for juiciness where average scores for all muscle $x$ ageing groups were always the lowest for AZ samples. In contrast, juiciness was similar for older grass-fed $A B$ and $B$ age groups and the younger AC grain-fed group for all three muscles (Table 5). The probable reason for the lack of differences in juiciness between younger grain- and older grass-fed cattle could be associated with the less tender meat of the older cattle compared to the meat of younger grain-fed cattle (Moholisa et al., 2017). According to Schönfeldt and Strydom (2011), more mastication would be required for samples from older animals (due to the increased cross-linking of the collagen with increased age) and, therefore, more saliva would be released and that may be perceived as juiciness. Lower juiciness scores for $A Z$ samples coincided with a trend towards higher cooking losses (BF) and generally higher purge recorded for all AZ muscles.

The sensory panel was able to distinguish between cuts of grain-fed ( $A Z$ and $A C$ ) and grass-fed animals ( $A B$ and $B$ ) on the grounds of flavour characteristics (Table 6). As indicated by Maughan et al. (2012) flavour differences are a consequence of differences in the chemical composition of the meat such as fat content, fatty acid composition and volatile compounds which include 1-penten-1-ol, 2-penten-1-ol. The $A B$ and $B$ cuts scored higher for pasture-like, animal-like, sour, and rancid flavour overtones and lower for roasted flavour than grain-fed cuts which is in agreement with previous studies (Melton et al., 1982; Mandell et al., 1998; Maughan et al., 2012; Strydom et al., 2013; O'Quinn et al., 2016). Grass-fed beef is expected to score higher for plant-like and other unique flavours due to higher poly-unsaturated fatty acid (PUFA) content (Scollan et al., 2006; Daley et al., 2010), in particular n-3 PUFA (O'Quinn, et al., 2016). The results of fatty acids reported by Moholisa et al. (2018) for the current study showed higher n-3 PUFA content in older grass- than in grain-fed beef. It is obvious that lipids play an important role in flavour recognition, and not only the amount but also the properties of fat will affect flavour perception (Melton et al., 1982; Maughan et al., 2012; O'Quinn, et al., 2016; Frank et al., 2016). Most of the differences found in different flavour overtones as reported above therefore relates to deposition of compounds (from feed source) into the fat component of the animal. Although more complicated than explained here (since more than 60 compounds were reported to contribute to the meaty aromatics; Shahidi, 1998), basically grain-fed cattle have a higher concentration of oleic and linoleic acid, whereas grass-fed cattle have high concentrations of alpha-linolenic and other n-3 polyunsaturated fatty acids (Vasta \& Priolo, 2006; Enser et al., 1998). High levels of linolenic acid impart flavours characterized as grassy and fishy, while oleic and linoleic acid were described as meaty or typical beef flavour (Wood et al., 2003). The review paper showed that the effect of fatty acid on meat flavour is due to the production of volatile, odorous, lipid oxidation products during cooking and the involvement of these with Maillard reaction products to form other volatiles which contribute to odour and flavour. In addition, skatole, which is involved in boar taint in pigs, is also more abundant in the fat of grassfed beef and could contribute to its specific flavour (Wood et al., 2003.

Although the lipid oxidation in the current study was not pronounced (Table 7), the trend towards higher scores for rancidity in grass-fed cuts may have been the result of oxidised unsaturated fatty acids (Moholisa et al., 2018). However, Spanier et al. (1997) reported that off-flavours develop when lipid oxidation takes place forming free-radicals that interact with other flavour constituents, but that this effect is limited with vacuum-packaging which inhibits oxidation. This could have been the same case with the current study, since the samples were vacuum aged. The other reason for high rancidity scores may also have been due to panelists' perception of atypical fatty flavours of pasture animals as rancid or negative flavours. Touraille and Girarad (1985) reported that rancid off-flavours increase when meat was aged exceptionally long, but no evidence of the effect of age or diet was reported. In the literature there is no agreement on the levels at which TBARS values could be considered as high. Rancid flavours could be detected at TBARS values of between 0.5 and $2 \mathrm{mg}$ malonaldehyde/kg tissue (Tarladgis et al., 1960; Greene \& Cumuze, 1982). A TBARS value of $1 \mathrm{mg}$ malonaldehyde/kg tissue was considered the threshold value for sensory detection of rancid flavours (Gray \& Pearson, 1987; Boles \& Parrish, 1990). Higher values for sourness scored for muscles of grain-fed cattle could be explained by the coupling of amino acids with organic acids which is noted as sour flavour in meat according MacLeod (1994). It is possible that grain-fed cattle had higher muscle energy 
levels and produced more lactic acid during rigor mortis to produce more acid like flavour overtones than pasture cattle.

According to Maughan et al. (2012), grassy, animal-like, sour and rancid flavours are considered as negative meat attributes by consumers, although they emphasised that this classification should be related to the population tested. In contrast to our study, Realini et al. (2013) evaluated consumers acceptability of beef from four different production systems and found that most of the consumers rated higher scores for beef from grass-fed animals and animals fed both grass and concentrate compared with beef from cattle fed concentrate only, showing a sensory preference for beef from pasture-based systems. Sañudo et al. (1998) described the significance of culinary cultural background on the acceptance of meat coming from pasture or feedlots, thereby indicating preferences for flavour or taste based on experience. This means if consumers are used to the flavour they will actually prefer it. The results of Strydom et al. (2013) further indicated that $A B$ class animals of different feeding regimes may be completely different products with regards to taste since their study included AB from grain and pasture. Both, Sañudo et al. (1998) and Strydom et al. (2013) emphasised the fact that the description (through classification) of two products that could be experienced differently by different consumers but without one-sided preference, is probably the main objective of classification if variation in consumer preferences is expected to define quality.

The higher overall flavour intensity scores of the muscles of the AC grain-fed compared to B grass-fed animals for LL muscle, and no flavour intensity differences for the AZ muscles compared to muscles of the grass-fed animals could be ascribed to differences in intramuscular fat (IMF) content of the different treatment groups. The AC grain-fed group had significantly higher IMF content than the B grass-fed group (Moholisa et al., 2018), and no significant differences in IMF could be observed between the AZ muscles and muscles of the grass-fed animals (Moholisa et al., 2018). Frank et al. (2016) clearly demonstrated the importance of IMF in flavour intensity. They found insignificant inherent flavour differences between beef produced on grass or grain at a similar IMF level, which was also observable in the current study. They also found that flavour volatiles and important taste-active non-volatile compounds increased with the amount of IMF, and that not only flavour becomes more intense with higher marbling levels, but desirable sensory attributes also become more consistent.

Although the sensory panel was able to differentiate between muscles of different feeding systems for other sensory attributes, no clear age or treatment effect could be observed for aroma intensity scores. Only older grass- fed ST had higher scores compared with AZ grain-fed samples, and this could possibly be ascribed to a very intense aromatic $\beta$-ionone that is formed through oxidation of $\beta$-carotene (found in grassfed animals), which likely comes from the feed (Calkins \& Hodgen, 2007).

\section{Conclusion}

It is clear that meat quality is a complex and multivariate concept which is influenced by multiple interacting factors. According to available literature, zilpaterol improves productivity of the beef industry, however, the current study showed that it achieves this at the expense of some of the meat quality attributes and therefore eating satisfaction. High moisture loss and poor meat colour in AZ treatment are considered as attributes having a negative influence on consumers decision to purchase meat. Poor water-holding capacity negatively affects tenderness and juiciness of meat. It is, therefore, important that when optimising productivity, meat quality, hence eating quality should be taken into consideration. Animal age alone could not show clear differences except when it was combined with diet in most of the parameters measured. The study also showed that no single feeding system can satisfy the eating experience and that there are other interacting factors. Consumer acceptability test could have given an insight of how different muscles were perceived in different feeding systems. In general, it is concluded that variability in beef and eating quality still exist amongst different feeding systems and if the purpose of the classification system is to describe and identify differences in the product that will relate to consumer experience, a pro-active quality control system is needed to avoid variability. Nevertheless, negative effects of different production systems as described maybe less likely noticed by consumers unless there is consumer education.

\section{Acknowledgements}

The authors are grateful for the assistance offered by the personnel of the Agricultural Research Council - Animal Production Institute, Irene, with the experimental work and in the rearing and processing of experimental animals and carcasses. The Agricultural Research Council is acknowledged for use of facilities. Technology Human Resource Industry Program and the Red Meat Research Development Trust are acknowledged for financial support.

\section{Authors' Contributions}

EM conducted the research as part of her PhD study, drafted and performed the technical preparation of the manuscript. PES devised the research idea. IV performed the sensory work. AH and PES supervised the study and revised the manuscript draft. All authors read and approved the final manuscript. 


\section{Conflict of Interest Declaration} There are no conflicts of interests.

\section{References}

American Meat Science Association (AMSA), 1995. Research Guidelines for Cookery, Sensory Evaluation and Instrumental Tenderness of Fresh Meat. National Livestock and Meat Board. Chicago, USA.

Arp, T.S., Howard, S.T., Woerner, D.R. \& Scanga J.A., 2014. Effects of ractopamine hydrochloride and zilpaterol hydrochloride supplementation on longissimus muscle shear force and sensory attributes of beef steers. J. Anim. Sci. 91, 5989-5997.

Avendaño-Reyes, L., Torres-Rodríguez, V., Meraz-Murillo, F.J., Pérez-Linares, C., Figueroa-Saavedra, F. \& Robinson, P.H., 2006. Effects of two ß-adrenergic agonists on finishing performance, carcass characteristics and meat quality of feedlot steers. J. Anim Sci. 84, 3259-3265.

Boakye, K. \& Mittal, G.S., 1996. Changes in colour of beef M. longissimus dorsi muscle during ageing. Meat Sci. 42, $347-$ 354.

Boles, J.A. \& Parrissh, F.C. Jr., 1990. Sensory and chemical characteristics of precooked microwave-reheatable pork roasts. J. Food Sci. 55, 618-620

Brewer, P. \& Calkins, C., 2003. Quality Traits of Grain-and Grass-Fed Beef. A Review. Lincoln: Nebreska Beef Cattle Reports. Paper 221.

Bruce, H.L. \& Ball, R.O., 1990. Post-mortem interactions of muscle temperature, pH and extension on beef quality. J. Anim. Sci. 68, 4167-4175.

Bruce, H. L., Stark, J.L. \& Beilken, S.L., 2004. The effects of finishing diet and post-mortem ageing on the eating quality of the M. longissimus thoracis of electrically stimulated Brahman steer carcasses. Meat Sci. 2, 261-268.

Calkins, C.R. \& Hodgen, J.M., 2007. A fresh look at meat flavor. Meat Sci. 77, 63-80.

Cônsolo, N.R.B., Ferrari, V.B., Mesquita, LG., Goulart, R.S. \& Silva, L.F.P., 2016. Zilpaterol hydrochloride improves beef yield, changes palatability traits, and increases calpain-calpastatin gene expression in Nellore heifers. Meat Sci. 121, 375-381.

Daley, C.A., Abbott, A., Doyle, P.S., Nader, G.A. \& Larson, S., 2010. A review of fatty acid profiles and antioxidant content in grass-fed and grain-fed beef. Nutr. J. 9, 1-12.

Delmore, R.J., Hodgen, M. \& Johnson, B.J., 2010. Perspectives on the application of zilpaterol hydrochloride in the United States beef industry. J. Anim. Sci. 88, 2825-2828.

Enser, M., Hallet, K.G., Hewett, B., Fursey, G.A., Wood, J.A.D. \& Harrington, G., 1998. Fatty acid content and composition of UK beef and lamb muscle in relation to production system and implications for human nutrition. Meat Sci. 49, 329-341.

Font-i-Furnols, M. \& Guerrero, L., 2014. Consumer preference, behaviour and perception about meat and meat products: An overview. Meat Sci. 98, 361-371.

Frank, D., Ball, A., Hughes, J., Krishnamurthy, R., Piyasiri, U., Stark, J., Watkins, P. \& Warner, R., 2016. Sensory and flavor chemistry characteristics of Australian beef: Influence of intramuscular fat, feed and breed. J. Agric. Food Chem. 64, 4299-4311.

French, P.C., Stanton, C., Lawless, F., O'Riordan, G., Monahan, F.J. \& Caffrey, P.J., 2000. Fatty acid composition including conjugated linoleic acid, of intramuscular fat from steers offered grazed grass, grass silage or concentrate-based diets. J. Anim. Sci. 78, 2849-2855.

Frylinck, L., Strydom, P.E., Webb, E.C. \& Du Toit, E., 2013. South African beef production systems on post-mortem muscle energy status and meat quality. Meat Sci. 93, 827-837.

Galli, I., Teira, G., Perlo, F., Bonato, P., Tisocco, O., Monje, A. \& Vittone, S., 2008. Animal performance and meat quality in cull cows with early weaned calves in Argentina. J. Anim. Sci. 79, 521-528.

Garmyn, A.J., Brooks, J.C., Hodgen, J.M., Nichols, W.T., Hutcheson, J.P., Rathmann, R.J. \& Miller, M.F., 2014 Comparative effects of supplementing beef steers with zilpaterol hydrochloride, ractopamine hydrochloride, or no beta-agonist on strip loin composition, raw and cooked color properties, shear force, and consumer assessment of steaks aged for fourteen or twenty-one days post-mortem. J. Anim. Sci. 92, 3670-3684.

Geesink, G.H., Smulders, F.J., Van Laack, H.L., Van der Kolk, J.H., Wensing, T. \& Breukink, H.J., 1993. Effects on meat quality of the use of clenbuterol in veal calves. J. Anim. Sci. 71, 1161-1170.

Gonzalez, J.M., Johnson, S.E., Thrift, T.A., Savell, J.D., Ouellette, S.E. \& Johnson, D.D., 2009. Effects of ractopaminehydrochloride on the fiber type distribution and shelf-life of six muscles of steers. J. Anim. Sci. 87, 1764-1771.

Government Notice No. R.342 of 19 March 1999. Regulations regarding the classification and marking of meat. Government Gazette of the Republic of South Africa, 19 March 1999.

Greene, B.E. \& Cumuze, T.H., 1982. Relationship between TBA numbers and inexperienced panelists' assessments of oxidized flavor in cooked beef. J. Food Sci. 47, 52-54

Gray, J.I. \& Pearson, A.M. 1987. Rancidity and warmed-over flavor. In: Advances in Meat Research, Eds: Pearson, A.M. \& Dutson, T.R., New York, USA. pp 221-270.

Henchion, M. M., McCarthy, M. \& Resconiac, V.C., 2017. Beef quality attributes: A systematic review of consumer perspectives. Meat Sci. 128, 7-7.

Hilton, G.G., Montgomery, J.L., Krehbiel, C., Yates, D. \& Hutcheson, J.N., 2009. Effects of feeding zilpaterol hydrochloride with and without monensin and tylosin on carcass cutability and meat palatability of beef steers. J. Anim. Sci. 87, 1394-1406. 
Hilton, G.G., Tatum, J.D., Williams, S.E., Belk, K.E., Williams, F.L., Wise, J.W. \& Smith, G.C. 1998. An evaluation of current and alternative systems for quality grading carcasses of mature slaughter cows. J. Anim. Sci. 76, 20942103.

Hope-Jones, M., Strydom, P.E., Frylinck, L. \& Webb, E.C., 2012. Effect of dietary beta-agonist treatment, vitamin D 3 supplementation and electrical stimulation of carcasses on colour and drip loss of steaks from feedlot steers. Meat Sci. 90, 607-612.

Irie, M., Izumo, A., \& Mohri, S., 1996. Rapid method for determining water-holding capacity in meat using video image analysis and simple formulae. Meat Sci. 42, 95-102.

Joo, S.T., Kim, Y.H., Hwang, Y.H. \& Ryu, Y.C., 2013. Control of fresh meat quality through manipulation of muscle fibre characteristics. Meat Sci. 95, 828-836.

Leheska, J.M., Montgomery, J.L., Krehbiel, C.R., Yates, D.A., Hutcheson, J.P., Nichols, W.T., Streeter, M., Blanton, JR., jr. \& Miller, M.F., 2009. Dietary zilpaterol hydrochloride. II. Carcass composition and meat palatability of beef cattle. J. Anim. Sci. 87, 1384-1393.

MacLeod, G., 1994. The flavour of beef. In: Flavour of Meat and Meat Products. Ed: Shahidi, F., Blackie Academic and Professional, London. pp. 4-37.

Mandell, I.B., Buchanan-Smith, J.G. \& Campell, C.P., 1998. Effects of forage feeding on carcass characteristics, fatty acid composition, and beef quality in Limousin-cross steers when time on feed is controlled. J. Anim. Sci. 76, 2619-2630.

Maughan, C., Tansawat, R., Cornforth, D., Ward, R. \& Martini, S., 2012. Development of a beef flavor lexicon and its application to compare the flavor profile. Meat Sci. 90, 116-121.

Melton, S.L., Amiri, M., Davis, G.W. \& Backus, W. R., 1982. Flavour and chemical characteristics of ground beef from grass, forage-grain- and grain-finished steers. J. Anim. Sci. 55, 77-87.

Meraz-Murillo, F.J., Avendaño-Reyes, L., Pérez-Linares, C., Figueroa-Saavedra B, Torres-Rodríguez, V, Guerra-Liera, J.E., Mellado, M. \& Macías-Cruz, U., 2017. Feedlot performance, carcass characteristics and meat quality of Zebu heifers supplemented with two $\beta$-adrenergic agonists. Anim. Prod. Sci. 57, 2125-2132.

Miller, M., 2007. Dark, Firm and Dry Beef. Beef facts. Beef product enhancement. National Cattlemen's Beef Association. Centennial, USA. http://fyi.uwex.edu/wbic/files/2011/04/Dark-Firm-and-Dry-Beef.pdf (Accessed on February 2019).

Moholisa, E., Strydom, P.E. \& Hugo, A., 2017. The effects of animal age, feeding regime and a dietary beta-agonist on tenderness of three beef muscles. J. Sci. Food Agric. 97, 2375-2381.

Moholisa, E., Strydom, P.E. \& Hugo, A., 2018. The effect of beef production system on proximate composition and fatty acid profile of three beef muscles. S. Afr. J. Anim. Sci. 48, 295-306.

Moloney, A.P., Allen, P., Joseph, R.L., Tarrant, P.V. \& Convey, E.M., 1994. Carcass and meat quality of finishing Friesian steers fed the $\beta$-adrenergic agonist L-644, 969. Meat Sci. 38, 419-432.

Moloney, A.P., Mooney, M, T., Troy, D, J. \& Keane, M.G., 2011. Finishing cattle at pasture at 30 months of age or indoors at 25 months of age: Effects on selected carcass and meat quality characteristics. Liv. Sci. 141, 17-23.

Monin, G. \& Ouali, A., 1992. Muscle differentiation and meat quality. In: Developments in Meat Science, Ed: Lawrie, R.A., Elsevier Applied Science, London: pp. 89-57.

Muir, P.D., Beaker, J.M. \& Bown, M.D., 1998. Effects of forage-based feeding and its effects on carcass and meat quality: A review. New Zeal. J. Agric. Res. 41, 623-635.

NRC, 1996. Nutrient Requirements of Beef Cattle. (7th ed.). National Academy Press. Washington, DC., USA.

Noci, F., Monahan, F.J., French, P. \& Moloney, A.P., 2005. The fatty acid composition of muscle fat and sabcutaneous adipose tissue of pasture fed beef heifers: Influence of duration of grazing. J. Anim. Sci. 83, 1167-1178.

O'Quinn, T.G., Woerner, D.R., Engle, T.E., Legako, J.F., Brooks, J.C., Belk, K.E. \& Tatum, J.D., 2016. Identifying consumer preferences for specific beef flavour characteristics in relation to cattle production and post-mortem processing parameters. Meat Sci. 112, 90-102.

Powell, V.H., 1991. Quality of beef loin steaks as influenced by animal age, electrical stimulation and ageing. Meat Sci, 30, 195-205.

Raharjo, S., Sofos, J.N. \& Schmidt, G.R., 1992. Improved speed, specificity, and limit of determination of an aqueous acid extraction thiobarbituric acid-C $\sim$ s. Method for measuring lipid peroxidation in beef. J. Agric. Food Chem. 50, 2182-2185.

Realini, C.E., Font i Furnols, M., Sañudo, C., Montossi, F., Oliver, M.A. \& Guerrero, L., 2013. Spanish, French and British consumers' acceptability of Uruguayan beef, and consumers' beef choice associated with country of origin, finishing diet and meat price. Meat Sci. 95, 14-21.

Ripoll, G., Albertí, P., Casasús, I. \& Blanco, M., 2013. Instrumental meat quality of veal calves reared under three management systems and color evolution of meat stored in three packaging systems. Meat Sci. 93, 336-343.

Rogers, H.R., Brooks, J.C., Hunt, M.C., Hilton, G.G., VanOverbeke, D.L., Killefer, J., Lawrence, T.E., Delmore, R.J., Johnson, B.J., Allen, D.M, Streeter, M.N., Nicholas, W.T., Hutcheson, J.P., Yates, D.A., Martin, J.N. \& Miller, M. F., 2010. Effects of zilpaterol hydrochloride feeding duration on beef and calf-fed Holstein strip loin steak colour. J. Anim. Sci. 88, 1168-1183.

Sañudo, C., Nute, G.R., Campo, M.M., María, G., Baker, A., Sierra, I., Enser, M.E. \& Wood, J.D., 1998. Assessment of commercial lamb meat quality by British and Spanish taste panels. Meat Sci. 48 (1/2), 91-100.

SAS, 1999, Statistical Analysis Systems User's Guide, Version 9, 1st printing, Volume 2. SAS Institute Inc., SAS Campus Drive, Cary, North Carolina. USA.

Sawyer, J.E., Mathis, C.P. \& Davis, B., 2004. Effects of feeding strategy and age on live animal performance, carcass characteristics, and economics of short-term feeding programs for culled beef cows. J. Anim. Sci. 82, 3646-3653. 
Schönfeldt, H.C. \& Strydom, P.E., 2011. Effect of age and cut on cooking loss, juiciness and flavour of South African beef. Meat Sci. 87, 180-190.

Scollan, N., Hocquette, J.F., Nürnberg, K., Dannenberger, D., Richardson, I. \& Moloney, A., 2006. Innovations in beef production systems that enhance the nutritional and health value of beef lipids and their relationship with meat quality. Meat Sci. 74, 17-33.

Snedecor, G.W. \& Cochran, W.G., 1980. Statistical Methods $\left(7^{\text {th }}\right.$ ed). 507, lowa State University Press.

Snedecor, G.W. \& Cochran, W.G., 1967. Statistical Methods, $\left(6^{\text {th }}\right.$ ed). The lowa State University Press, Ames, lowa USA. Chapter 4 and 11.

Shapiro, S.S. \& Wilk, M.B., 1965. An analysis of variance test for normality (Complete Samples). Biometrika, 52, 591611.

Shahidi, F., 1998. Flavour of muscle foods - An overview. In: Flavour of Meat, Meat Products, and Seafoods. Ed: Shahidi, F., London: Blackie Academic and Professional. pp. 1-4.

Shorthose, W.R. \& Harris, P.V. 1990. Effect of animal age on the tenderness of selected beef muscles. J. Food Sci. 55, 1-7.

Sonji, Z. \& Muchenje, V., 2017. Should the South African red meat classification system be revised or maintained? A review. S. Afr. J. Anim. Sci. 47, 583-594.

Spanier, A.M., Flares, M., McMillin, K.W. \& Bidner, T.D., 1997. The effect of post-mortem ageing on meat flavour quality in Brangus beef. Correlation of treatments, sensory, instrumental and chemical descriptors. Food Chem. 59, 531538.

Strydom, P.E., Hope Jones, M. \& Webb, E.C., 2011. The effects of a beta-agonist treatment, Vitamin D3 supplementation and electrical stimulation on meat quality of feedlot steers. Meat Sci. 89, 462-468.

Strydom, P., Sehoole, O.C., Hope-Jones, M. \& van Heerden, S.I., 2013. Sensory tenderness of three beef cuts from carcasses of different age classifications, diets and aged over two ageing periods. Proc $59^{\text {th }}$ Int. Cong. Meat Sci. Technol. Izmir, Turkey, 18-23 August 2013. S10-7.

Strydom, P.E., Frylinck, L., Montgomery, J.L. \& Smith, M.F., 2009. The comparison of three beta-agonists for growth performance, carcass characteristics and meat quality of feedlot cattle. Meat Sci. 81, 557-564.

Tatum, J.D., 2008. Producing flavorful beef. Certified Angus Beef LLC, 1-19. http://www.cabpartners.com/articles/news/231/tatum_producing_flavorful_beef.pdf. (Accessed on April 2016).

Touraille, C. \& Girard, J.P., 1985, Revue des facteurs ante et post-mortem influençant 86 la flaveur de la viande et celle des produits carnés. Bull Tech Centre de Recherches Zootechniques eteterinaires Theix INRA 60, 83-97.

Tarladgis, B.G., Watts, B.M., Younathan, M.T. \& Dugan, L., 1960. A distillation method for the quantitative determination of malonaldehyde in rancid foods. J. Am. Oil Chem. Soc. 37, 44-48.

Van Elswyk, M.E. \& McNeill, S.H., 2014. Impact of grass/forage feeding versus grain finishing on beef nutrients and sensory quality: The U.S. experience. Meat Sci. 96, 535-540.

VanOverbeke, D.L., Hilton, G.G., Green, J., Hunt, M., Brooks, C., Killefer, J., Streeter, M.N., Hutcheson, J.P., Nicholas, W.T., Allen, D.M. \& Yates, D. A., 2009. Effect of zilpaterol hydrochloride supplementation of beef steers and calffed Holstein steers on the colour stability of top sirloin butt steaks. J. Anim. Sci. 87, 3669-3676.

Vasta, V. \& Priolo, A., 2006. Ruminant fat volatiles as affected by diet. A review. Meat Sci. 73, 218-228.

Vestergaard, M., Oksbjerg, N. \& Henckel, P., 2000. Influence of feeding intensity, grazing and finding feeding on muscle fibre characteristics and meat colour of semitendinosus, longissimus dorsi and supraspinatus muscles of young bulls. Meat Sci. 54, 177-185.

Vestergaard, M., Henckel, P., Oksbjerg, N. \& Sejrsen, K. 1994. The effect of cimaterol on muscle fiber characteristics, capillary supply, and metabolic potentials of longissimus and semitendinosus muscles from young Friesian bulls. J. Anim. Sci. 72, 2298-2306.

Wood, J.D., Richardson, R.I., Nute, G.R., Kasapidou, E., Sheard, P.R. \& Enser, M., 2003. Effects of fatty acids on meat quality: A review. Meat Sci. 66, 21-23.

Young O.A., Priolo, A., Simmons, N.J. \& West, J., 1999. Effects of rigor attainment temperature on meat blooming and colour on display. Meat Sci. 52, 47-56. 